\title{
Elective orthopedic and cardiopulmonary bypass surgery causes a reduction in serum endostatin levels
}

\author{
Torbjörn Åkerfeldt ${ }^{1 *}$, Lena Gunningberg ${ }^{2}$, Christine Leo Swenne ${ }^{2}$, Göran Ronquist ${ }^{1}$ and Anders Larsson ${ }^{1}$
}

\begin{abstract}
Background: Endostatin is an endogenous inhibitor of angiogenesis that inhibits neovascularisation. The aim of the study was to evaluate the effect of elective surgery on endostatin levels.

Methods: Blood samples were collected prior to elective surgery and 4 and 30 days postoperatively in 2 patient groups: orthopedic surgery $(n=27)$ and coronary bypass patients $(n=21)$. Serum endostatin levels were measured by ELISA.
\end{abstract}

Results: Serum endostatin was significantly reduced 30 days after surgery in comparison with presurgical values in both the orthopedic ( $P=0.03$ ) and cardiopulmonary surgery $(P=0.04)$ group.

Conclusion: Serum endostatin is reduced 30 days after surgery. This reduction would favor angiogenesis and wound-healing.

Keywords: Angiogenesis, CRP, ELISA, Endostatin, Elective surgery

\section{Background}

Collagen XVIII is a basement membrane protein with structural similarities to collagen XV [1,2]. Collagen XVIII contains an anti-angiogenic C-terminal non-collagenous domain known as endostatin [3,4]. Endostatin has a molecular weight of $22 \mathrm{kDa}$ and is an endogenous inhibitor of angiogenesis formed by the proteolytic cleavage of the C-terminal domain [5]. The formation of endostatin is mainly induced by elastase, metalloproteinases (MMP) -3, $-7,-9,-13,-14$ and -20 , and cathepsin L [6-8].

Endostatin plays a role in the local balance of angiogenesis as a potent inhibitor and has been suggested to be of particular importance in the growth and spreading of malignant diseases. Endostatin has been shown to inhibit the growth of several tumors of both human and mouse origin [9-13]. Angiogenesis is also important for physiological wound-healing. Healing of cutaneous wounds in mice may be inhibited by recombinant endostatin treatment [14]. Overexpression of endostatin in keratinocytes has also been shown to delay woundhealing [15]. Endostatin has also been shown to inhibit wound repair of lung epithelial cells [16], and to impair healing of gastric ulcers [17].

The endostatin levels in surgical patients may thus influence the rate of wound-healing. Delayed woundhealing is an important surgical problem and it is associated with increased complications such as infections and also increased mortality [18-21].

The aim of the present study was to investigate the effect of postsurgical inflammation on serum endostatin levels in humans. The patients were treated with elective surgery, and thus the patients had low presurgical inflammatory activities. The operations induce a strong inflammatory response and thus are suitable for investigating the effects of traumatic inflammatory response on serum endostatin levels during the wound-healing period [22]. Results from two surgery groups were compared to strengthen the significance of any findings.

\footnotetext{
* Correspondence: torbjorn.akerfeldt@akademiska.se

${ }^{1}$ Department of Medical Sciences, Section of Clinical Chemistry, Uppsala

University, Uppsala, Sweden

Full list of author information is available at the end of the article
} 


\section{Methods}

\section{Study population}

Elective orthopedic surgery $(\mathrm{n}=27,13$ males and 14 females) and elective cardiopulmonary bypass surgery ( $\mathrm{n}=21,18$ males and 3 females) patients, at the Uppsala University Hospital were included in the study. Blood sampling was performed prior to surgery and on day 4 and day 30 after surgery. The blood samples were collected in Vacutainer tubes (367815, Becton, Dickinson, Franklin Lakes, NJ, USA) without additives, and after clotting the samples were centrifugated at room temperature and the sera were collected and frozen at $-22^{\circ} \mathrm{C}$. The study was approved by the local ethical board at Uppsala University (2004:237) and all patients signed an informed consent prior to inclusion in the study.

\section{C-reactive protein (CRP) assay}

Serum CRP (reagent: 6 K2601) was analyzed on an Architect Ci8200 analyzer (Abbott Laboratories, Abbott Park, IL, USA). The CRP assay had a total coefficient of variation $(\mathrm{CV})$ of $0.8 \%$ at $8 \mathrm{mg} / \mathrm{L}$ and the assay calibrator was traceable to CRM 470.

\section{Endostatin ELISA}

Serum levels of endostatin were analyzed using a commercially available ELISA kit for endostatin (DY1098, R\&D Systems, Minneapolis, MN, USA). The assays had a total coefficient of variation $(\mathrm{CV})$ of approximately $6 \%$.

\section{Statistical calculations}

Statistical analysis was performed with Statistica 7.1 (StatSoft, Tulsa, OK, USA). Comparisons between presurgical and postsurgical samples were performed with the Wilcoxon matched pair test. Association between endostatin and CRP was investigated with Spearman rank correlation. Descriptive statistics for the different sampling times were reported as median and IQR (interquartile range). $P<0.05$ was regarded as statistically significant throughout the study.

\section{Results}

\section{Patient characteristics and CRP values}

The mean age was 67 years (range 45 to 80 years) for the orthopedic patients and 69 years (range 48 to 84 years) for the cardiopulmonary bypass patients. In the orthopedic group (Figure 1), median CRP value prior to surgery was $1.9 \mathrm{mg} / \mathrm{L}$ (IQR $1.2-8.7$ ). Four days after surgery the median value was $137.3 \mathrm{mg} / \mathrm{L}$ (IQR 104.1 178.2) and 30 days after surgery the median value was $5.1 \mathrm{mg} / \mathrm{L}$ (IQR 2.1 - 11.2). The corresponding values for the cardiopulmonary surgery group (Figure 2) was: CRP value prior to surgery $3.3 \mathrm{mg} / \mathrm{L}$ (IQR 1.0 - 7.6), 4 days after surgery $167.0 \mathrm{mg} / \mathrm{L}(103.7$ - 222.7) and 30 days after surgery $3.4 \mathrm{mg} / \mathrm{L}(2.0-5.6)$.

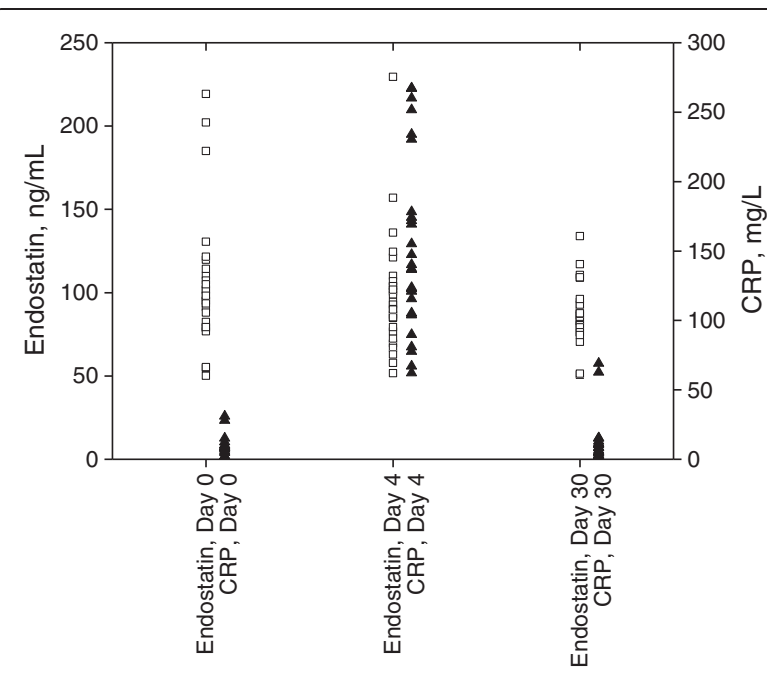

Figure 1 Endostatin and C-reactive protein (CRP) values in individual patients at day 0 , day 4 and day 30 after orthopedic surgery.

\section{Endostatin values}

In the orthopedic group (Figure 1) the presurgical median endostatin value was $98.1 \mathrm{ng} / \mathrm{mL}$ (IQR 79.3 - 114.2). Four days after surgery the median value was $92.8 \mathrm{ng} / \mathrm{mL}$ (IQR 76.7 - 106.9) ( $P=0.23)$ and 30 days after surgery the median value was $86.2 \mathrm{ng} / \mathrm{mL}$ (IQR 77.7 - 95.3) $(P=0.03$ versus presurgical values). The median endostatin value in the cardiopulmonary surgery group (Figure 2) was $90.0 \mathrm{ng} / \mathrm{mL}$ (IQR 81.9 - 105.5). Four days after surgery the median values was $88.1 \mathrm{ng} / \mathrm{mL}$ (IQR 77.5 - 112.1) $(P=0.85)$ and 30 days after surgery the median value was $76.9 \mathrm{ng} / \mathrm{mL}$ (IQR 67.3 - 90.8) ( $P=0.04$ versus presurgical values).

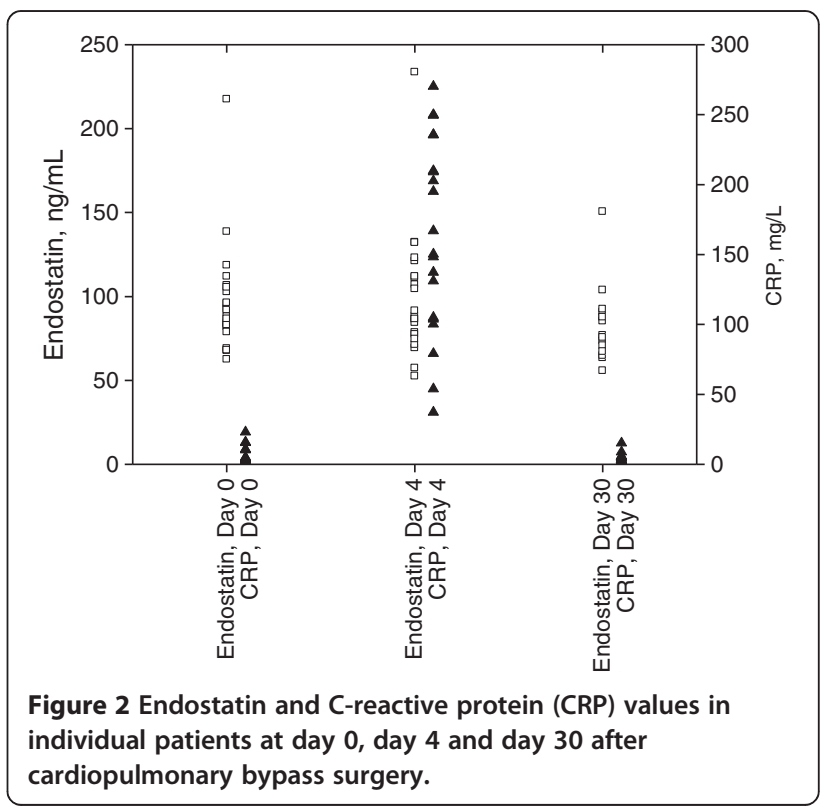


Table 1 Spearman rank correlations between C-reactive protein (CRP) and endostatin at day 0 , day $\mathbf{4}$ and day 30 in the orthopedic and the cardiopulmonary surgery groups

\begin{tabular}{lll}
\hline Orthopedic surgery & $\mathbf{R}$ & $\boldsymbol{P}$-value \\
\hline Day 0 & 0.35 & 0.071 \\
Day 4 & 0.44 & 0.020 \\
Day 30 & 0.31 & 0.15 \\
\hline Cardiopulmonary surgery & & \\
\hline Day 0 & 0.43 & 0.055 \\
Day 4 & 0.54 & 0.012 \\
Day 30 & 0.29 & 0.31 \\
\hline
\end{tabular}

\section{Correlation between endostatin and CRP values}

There were significant Spearman rank correlations between endostatin and CRP at day 4 in both the orthopedic $(\mathrm{R}=0.44, P=0.020)$ and the cardiopulmonary surgery $(\mathrm{R}=0.54, P=0.012)$ groups (Table 1$)$. The Spearman rank correlations between endostatin and CRP at day 0 and day 30 did not fulfill the preset criteria for significance in this study $(P<0.05)$.

\section{Discussion}

Apart from being a breakdown product from collagen XVIII, endostatin is a potent endogenous angiogenesis inhibitor and is regulated in balance with vascular endothelial growth factor (VEGF) [10]. Endostatin has been shown to be a marker of breakdown and remodelling of the extracellular matrix in various diseases [23-25]. Therefore, one plausible explanation for the present associations could be that circulating endostatin also mirrors an increased extracellular remodelling. The surgical procedures result in local tissue damage leading to the initiation of an acute phase reaction and a woundhealing process involving cutaneous, subcutaneous and deeper tissues. The highest CRP values were observed 4 days after surgery. At this sampling time there was a positive Spearman rank correlation between CRP and endostatin concentrations in both patient groups. Thus, during the acute phase there was a positive correlation between inflammatory response and endostatin values. At the same time there was a postoperative endostatin decrease during the postsurgical phase. This indicated that there were several pathways that influenced endostatin concentrations after surgery. One of the influential factors appeared to be the inflammatory response although the surgical process initiated other systems that led to a decrease in endostatin levels.

\section{Conclusions}

The largest difference in serum concentration of endostatin was generated between the samples 'before surgery' and 'day 30'. At day 4 the wound-healing process had just been initiated while it was more active at day 30 . The decline in endostatin concentrations favors neovascularisation, which is of importance for wound-healing. Further studies are warranted to explore the different mechanisms that influence endostatin during the woundhealing process.

\section{Abbreviations}

CRP: C-reactive protein; ELISA: Enzyme-linked immunosorbent assay;

IQR: Interquartile range; VEGF: Vascular endothelial growth factor.

Competing interests

The authors declare that they have no competing interests.

\section{Authors' contributions}

$L G, C L S$ and $T \AA$ participated in the design of the study. $L G$ and $C L S$ were responsible for sample collections and logistics. AL, TÅ and GR performed the laboratory testing. TA and AL drafted the manuscript. All authors read and approved the final manuscript.

\section{Acknowledgements}

This study was financially supported by the Uppsala University Hospital Research Fund.

\section{Author details}

'Department of Medical Sciences, Section of Clinical Chemistry, Uppsala University, Uppsala, Sweden. ${ }^{2}$ Department of Public Health and Caring Sciences, Uppsala University, Uppsala, Sweden.

Received: 24 June 2014 Accepted: 23 October 2014

Published online: 08 November 2014

\section{References}

1. Muragaki Y, Abe N, Ninomiya Y, Olsen BR, Ooshima A: The human alpha 1 (XV) collagen chain contains a large amino-terminal non-triple helical domain with a tandem repeat structure and homology to alpha 1(XVIII) collagen. J Biol Chem 1994, 269(6):4042-4046.

2. Rehn M, Pihlajaniemi T: Alpha $1(\mathrm{XVIII})$, a collagen chain with frequent interruptions in the collagenous sequence, a distinct tissue distribution, and homology with type XV collagen. Proc Natl Acad Sci U S A 1994, 91(10):4234-4238.

3. O'Reilly MS, Boehm T, Shing Y, Fukai N, Vasios G, Lane WS, Flynn E, Birkhead JR, Olsen BR, Folkman J: Endostatin: an endogenous inhibitor of angiogenesis and tumor growth. Cell 1997, 88(2):277-285.

4. Sasaki T, Fukai N, Mann K, Gohring W, Olsen BR, Timpl R: Structure, function and tissue forms of the C-terminal globular domain of collagen XVIII containing the angiogenesis inhibitor endostatin. EMBO J 1998, 17(15):4249-4256.

5. Muntner P, He J, Hamm L, Loria C, Whelton PK: Renal insufficiency and subsequent death resulting from cardiovascular disease in the United States. J Am Soc Nephrol 2002, 13(3):745-753.

6. Felbor U, Dreier L, Bryant RA, Ploegh HL, Olsen BR, Mothes W: Secreted cathepsin $\mathrm{L}$ generates endostatin from collagen XVIII. EMBO J 2000, 19(6):1187-1194.

7. Ferreras M, Felbor U, Lenhard T, Olsen BR, Delaisse J: Generation and degradation of human endostatin proteins by various proteinases. FEBS Lett 2000, 486(3):247-251.

8. Wen W, Moses MA, Wiederschain D, Arbiser JL, Folkman J: The generation of endostatin is mediated by elastase. Cancer Res 1999, 59(24):6052-6056.

9. Liu Z, Li Y, Zhao W, Ma Y, Yang X: Demonstration of vasculogenic mimicry in astrocytomas and effects of Endostar on U251 cells. Pathol Res Pract 2011, 207(10):645-651.

10. Folkman J: Antiangiogenesis in cancer therapy - endostatin and its mechanisms of action. Exp Cell Res 2006, 312(5):594-607.

11. Abdollahi A, Hahnfeldt P, Maercker C, Grone HJ, Debus J, Ansorge W, Folkman J, Hlatky L, Huber PE: Endostatin's antiangiogenic signaling network. Mol Cell 2004, 13(5):649-663.

12. Chen W, Fu J, Liu Q, Ruan C, Xiao S: Retroviral endostatin gene transfer inhibits human colon cancer cell growth in vivo. Chin Med J (Engl) 2003, 116(10):1582-1584 
13. Li J, Dong $X, X u Z$, Jiang $X$, Jiang $H$, Krissansen GW, Sun $X$ : Endostatin gene therapy enhances the efficacy of paclitaxel to suppress breast cancers and metastases in mice. J Biomed Sci 2008, 15(1):99-109.

14. Michaels J, Dobryansky M, Galiano RD, Bhatt KA, Ashinoff R, Ceradini DJ, Gurtner GC: Topical vascular endothelial growth factor reverses delayed wound healing secondary to angiogenesis inhibitor administration. Wound Repair Regen 2005, 13(5):506-512.

15. Seppinen L, Sormunen R, Soini Y, Elamaa H, Heljasvaara R, Pihlajaniemi T: Lack of collagen XVIII accelerates cutaneous wound healing, while overexpression of its endostatin domain leads to delayed healing. Matrix Biol 2008, 27(6):535-546.

16. Richter AG, McKeown S, Rathinam S, Harper L, Rajesh P, McAuley DF, Heljasvaara R, Thickett DR: Soluble endostatin is a novel inhibitor of epithelial repair in idiopathic pulmonary fibrosis. Thorax 2009, 64(2):156-161.

17. Ma L, Elliott SN, Cirino G, Buret A, Ignarro LJ, Wallace JL: Platelets modulate gastric ulcer healing: role of endostatin and vascular endothelial growth factor release. Proc Natl Acad Sci U S A 2001, 98(11):6470-6475.

18. Stechmiller JK: Understanding the role of nutrition and wound healing. Nutr Clin Pract 2010, 25(1):61-68.

19. Mnif H, Koubaa M, Zrig M, Trabelsi R, Abid A: Elderly patient's mortality and morbidity following trochanteric fracture. A prospective study of 100 cases. Orthop Traumatol Surg Res 2009, 95(7):505-510.

20. Martin CT, Pugely AJ, Gao Y, Wolf BR: Risk factors for thirty-day morbidity and mortality following knee arthroscopy: a review of 12,271 patients from the national surgical quality improvement program database. J Bone Joint Surg Am 2013, 95(14):e981-10.

21. Namba RS, Inacio MC, Paxton EW: Risk factors associated with deep surgical site infections after primary total knee arthroplasty: an analysis of 56,216 knees. J Bone Joint Surg Am 2013, 95(9):775-782.

22. Akerfeldt T, Larsson A: Pentraxin 3 increase is much less pronounced than C-reactive protein increase after surgical procedures. Inflammation 2011, 34(5):367-370

23. Sund $M$, Xie $L$, Kalluri $R$ : The contribution of vascular basement membranes and extracellular matrix to the mechanics of tumor angiogenesis. APMIS 2004, 112(7-8):450-462.

24. Ramazani M, Lundin C, Sund M: Increased circulating levels of basementmembrane components in patients with abdominal aortic aneurysms - a pilot study. Eur J Vasc Endovasc Surg 2011, 42(4):484-487.

25. Sund M, Kalluri R: Tumor stroma derived biomarkers in cancer. Cancer Metastasis Rev 2009, 28(1-2):177-183.

doi:10.1186/s40001-014-0061-9

Cite this article as: Åkerfeldt et al.: Elective orthopedic and cardiopulmonary bypass surgery causes a reduction in serum endostatin levels. European Journal of Medical Research 2014 19:61.

\section{Submit your next manuscript to BioMed Central and take full advantage of:}

- Convenient online submission

- Thorough peer review

- No space constraints or color figure charges

- Immediate publication on acceptance

- Inclusion in PubMed, CAS, Scopus and Google Scholar

- Research which is freely available for redistribution 